Mariusz Mohyluk

\title{
Wacław Makowski o radzieckim prawie karnym
}

Keywords: Soviet penal law, sovietology

\section{Summary}

Wacław Makowski (1880-1942) was an outstanding Polish politician, lawyer and scientist. He was one of the authors of the 1932 criminal code and of Polish constitution of 1935 (so called April Constitution). His scientific interests included also Soviet penal law. He wrote the preface to Soviet Penal Code of 1927 (Kodeks karny Rosji Sowieckiej 1927, Warszawa 1928). His critical remarks on Soviet penal law, although not very spacious, are important, because he questioned common opinion in the scientific Western world about this law. He criticized opinion that Soviet penal law was based on views of the Italian school of positive law. He started the discussion on Soviet penal law in Polish jurisprudence. This discussion seemed to be very interesting, but it was interrupted by the outbreak of World War II.

Polskim naukowcom zajmującym się problematyką społeczną okresu międzywojennego nieobojętne były przemiany w Rosji bolszewickiej. Badacze systemu radzieckiego, głównie prawnicy, chętnie zajmowali się prawem państw totalitarnych, jego podstawami teoretycznymi i praktyką. Od początku lat dwudziestych rozpoczął się cały nurt badań indywidualnych i zinstytucjonalizowanych ${ }^{1}$. Spośród instytucji najważniejszy był wileński Instytut Naukowo-Badaw-

1 Zob. M. Kornat, Bolszewizm.Totalitaryzm. Rewolucja. Rosja. Początki sowietologii i studiów nad systemami totalitarnymi w Polsce (1918-1939), Kraków 2004 i tam dalsza literatura na ten temat; M. Mohyluk, Prawo radzieckie w nauce i publicystyce prawniczej II Rzeczypospolitej - stan badań i problemy badawcze, „Miscellanea Historico-Iuridica”, t. 2, Białystok 2004, s. 67-81. 
czy Europy Wschodniej, którego twórców (m.in. Stefana Ehrenkreutza, Wiktora Sukiennickiego, Stanisława Swianiewicza, Witolda Staniewicza i Mariana Zdziechowskiego) wywodzących się głównie z Uniwersytetu Stefana Batorego uważa się za prekursorów polskiej szkoły sowietologicznej. Za pierwszą pracę poświęconą badaniom nad prawem i ustrojem Związku Sowieckiego można uznać książkę I. Czumy Konstytucja Rosji Sowieckiej². Problematyką tą zajmowali się również inni wybitni prawnicy II Rzeczypospolitej, tacy jak: Konstanty Grzybowski, Wacław Komarnicki, Władysław Leopold Jaworski, Wacław Makowski i Szymon Rundstein.

Do poznania radzieckiego ustawodawstwa karnego wydatnie przyczynili się Rafał Lemkin ${ }^{3}$, Juliusz Makarewicz ${ }^{4}$ oraz Wacław Makowski, którego analizie poglądów poświęcę dalszą część artykułu. To właśnie ci autorzy - moim zdaniem - opublikowali najwartościowsze pod względem merytorycznym prace, tj. Kodeks karny republik sowieckich ${ }^{5}$ i Kodeks karny Rosji Sowieckiej 19276. Jednakże należy tu podkreślić, że dotyczyły one wyłącznie kształtującego się w latach 1917-1927 radzieckiego materialnego prawa (ustawodawstwa) karnego, a więc ich rozważania były zawężone do określonego przedziału czasowego i określonej problematyki karnistycznej.

W latach 1917-1939 radzieckie prawo karne ulegało licznym zmianom. Przyczyn takiego stanu rzeczy można upatrywać po pierwsze - w bezwzględnym dążeniu rewolucyjnej dyktatury proletariatu do przebudowy społeczno-politycznej państwa radzieckiego i po drugie - w pobudkach czysto ideologicznych. Począwszy od październikowego puczu w Pałacu Zimowym, bolszewicy w roku 1917 (właściwie do końca 1920 r.) podjęli walkę z zewnętrznym i wewnętrznym wrogiem klasowym. „Stary aparat państwowy zostanie doszczętnie rozbity i stworzony zostanie nowy aparat rządzenia w postaci organizacji radzieckich" zapowiadał W. I. Lenin w referacie wygłoszonym 7 listopada 1917 r. na posiedzeniu piotrogradzkiej Rady Delegatów Robotniczych i Żołnierskich. Rewolucyjnym sądom polecono, aby kierowały się „w swoich orzeczeniach i wyrokach ustawami obalonych rządów tylko o tyle, o ile takowe nie zostały obalone przez rewolucję i nie sprzeciwiają się rewolucyjnemu sumieniu i rewolu-

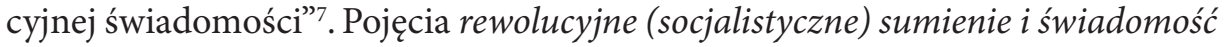

2 I. Czuma, Konstytucja Rosji Sowieckiej, Kraków 1923.

3 Znany na forum nauki światowej jako twórca pojęcia genocidum (ludobójstwo) i autor książki The Axis Rule in Occupied Europe: Laws of Occupation, Analisis of Government,Proposals for Redress, Washington 1944.

${ }^{4}$ Współtwórca polskiego Kodeksu karnego z 1932 r., znany w Europie jako autor dzieła pt. Einführung in die Philosophe des Straftrechts auf Entwicklungsgeschichlichche Grundwag, Stuttgart 1906.

J. Makarewicz, Kodeks karny republik sowieckich, Warszawa 1926.

6 R. Lemkin, Kodeks karny Rosji Sowieckiej 1927, Warszawa 1928.

Punkt 5 Dekretu o sądzie nr 1 z 24 listopada 1917 r. stanowi: „Sądy lokalne rozpatrują sprawy w imieniu Republiki Rosyjskiej i kierują się w swoich orzeczeniach i wyrokach ustawami obalonych rządów tylko o tyle, o ile takowe nie zostały obalone przez rewolucję i nie sprzeciwiają się rewolucyjnemu sumieniu i rewolucyjnej świadomości prawnej”. W art. 36 Dekretu o sądzie nr 2 z 15 lutego 1918 r. 
prawna stały się więc - jak zauważył A. Bosiacki - „kluczową klauzulą generalną

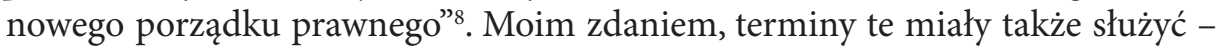
począwszy od Dekretu o sądzie nr 1 - szybkiej deprecjacji i likwidacji przedrewolucyjnego ustawodawstwa.

W ten sposób dotychczasowy system prawny zaczęto traktować posiłkowo, a nadrzędną doktryną porządku państwowego stała się doktryna praworządności rewolucyjnej, u której źródeł legły właśnie wymogi rewolucyjnego sumienia i klasowe interesy proletariatu. W związku z tym kształtujące się prawo karne zmieniało całkowicie swoją treść klasową, gdyż miało chronić wyłącznie zdobyczy państwa robotników i chłopów przed zamachami ze strony jego przeciwników. Ten klasowy charakter prawa karnego wywodzono z marksistowskiego założenia, że w ogóle prawo pojawia się dopiero wówczas, gdy powstaje państwo. „Historia wykazuje - pisał Lenin - że państwo jako aparat przymusu powstawało tylko tam i wtedy, gdzie i kiedy powstawał podział społeczeństwa na klasy - tzn. podział na takie grupy ludzi, z których jedne mogą stale przywłaszczać sobie prace innych, gdzie jeden wyzyskuje drugiego" ${ }^{9}$. Prawo karne istniejące tylko w państwie chroniło interesy klasy panującej, a więc „wyzyskiwaczy przed zamachami ze strony wyzyskiwanych”. Podążając tym tokiem myślenia, trudno mówić o państwie i prawie radzieckim, co jest oczywistą sprzecznością w świetle zaistniałych faktów historycznych. Nie ma bowiem wątpliwości, że od 1917 r. władzę skutecznie przejmowali bolszewicy, którzy na gruzach carskiego gmachu budowali państwo robotniczo-chłopskie, gdzie nadrzędne stało się prawo karne nowego typu. Prawo to powstawało spontanicznie, ad hoc, a jego źródłem stawały się rewolucyjne sumienie i świadomość. Mieli je w swoim arsenale bolszewicy. Pierwszym zadaniem ich dyktatury było złamanie oporu obalonych klas i obrona kraju przed najazdem z zewnątrz. „Państwo sowieckie - pisał Konstanty Grzybowski - nie jest państwem prawnym. Podstawą działalności organów państwowych oraz praw i obowiązków obywateli nie są obiektywne normy prawne, uprzednio opublikowane i mogące ulec zmianie tylko w pewien z góry określony sposób. Naczelną zasadą porządku państwowego jest pewna doktryna polityczno-socjalna, doktryna komunistyczna, a normy prawa pisanego stanowią jedynie wytyczne" ${ }^{10}$. Ignacy Czuma słusznie zauważył, że prawo w Związku Radzieckim

(w części jedenastej O obowiązujących ustawach) mamy: „W sprawach cywilnych i karnych sąd kieruje się ustawami cywilnymi i karnymi dotychczas obowiązującymi tylko o tyle, o ile takowe nie zostały uchylone przez dekrety Centralnego Komitetu Wykonawczego i Rady Komisarzy Ludowych oraz nie są sprzeczne z socjalistyczną świadomością prawną [...]”. W art. 3 Dekretu o sądzie nr 3 z 13 lipca 1918 r. natomiast umożliwiono „lokalnym sądom ludowym orzekanie kar do 5-ciu lat pozbawienia wolności, w oparciu o dekrety Rządu Robotniczo-Chłopskiego i socjalistyczne sumienie". Zob. A. Bosiacki, Utopia władza prawo. Doktryna i koncepcje prawne „bolszewickiej” Rosji 1917-1921. Warszawa 1999, s. 341-353.

${ }^{8}$ Ibidem, s. 153.

${ }^{9}$ W. I. Lenin, O państwie, Warszawa 1950, s. 11.

${ }^{10}$ Antykomunizm polski. Tradycje intelektualne, pod red. B. Szlachty, Kraków 2000, s. 145-146. 
„jest systemem norm socjalnych, wytwarzanych i utrzymywanych przez określoną siłę społeczną. Prawo tworzą ci, którzy mają siłę, norm tych broni w dalszej konsekwencji ta sama siła, która powstanie normy inspiruje, która normy dla siebie urządza. Tak wygląda teza sowiecka o prawie. Ponieważ zaś w sowietach siła ta formalnie należy do klasy proletariatu, zatem łatwo nam określić sobie kierunek treściowy wytwarzanych norm. To jest całe usprawiedliwienie prawa"11.

Decydującą rolę w rozwoju radzieckiego prawa karnego odegrały Przewodnie zasady prawa karnego RSFRR z 12 grudnia 1919 r. ${ }^{12}$ Były one pierwowzorem części ogólnej przyszłego kodeksu karnego i stanowiły w zasadzie podsumowanie doświadczeń sądów radzieckich w ciągu pierwszych dwu lat ich istnienia. We wstępie Przewodnich zasad... sformułowano zasady ogólne radzieckiego „proletariackiego prawa karnego". Podkreślono w nim, że proletariat, który zdobył władzę, „zburzył burżuazyjny aparat państwowy” i „całe prawo burżuazyjne, jako system norm, które za pomocą zorganizowanej przemocy podtrzymywały równowagę interesów klas społecznych na korzyść klas panujących (burżuazji i obszarników)".W końcowej części wstępu określono zadania radzieckiego prawa karnego: „Celem oszczędzania sił, uzgodnienia i scentralizowania rozproszonych poczynań proletariat winien wypracować zasady okiełznania swych wrogów klasowych, stworzyć metodę walki z wrogami, nauczyć się posługiwania tą metodą. Przede wszystkim zaś winno to dotyczyć prawa karnego, którego zadaniem jest walka z tymi, co naruszają nowezasady współżycia,kształtujące sięprzejściowo w okresie dyktatury proletariatu (podkr. moje - M. M.). Dopiero po ostatecznym złamaniu oporu obalonych klas burżuazyjnych i pośrednich, po wprowadzeniu ustroju komunistycznego, proletariat zniszczy również państwo jako organizację przemocy i prawo jako funkcję państwa"13. Jak widać, cel - mglista wizja ustroju komunistycznego - miał uświęcać środki, proletariackie prawo radzieckie.

Niektóre z wyżej opisanych cech radzieckiego prawa karnego znalazły oddźwięk w dorobku W. Makowskiego (1880-1942), wybitnego w II Rzeczypospolitej polityka, prawnika i uczonego (współtwórcy kodeksu karnego z 1932 r. i konstytucji kwietniowej z 1935 r. $)^{14}$.

${ }^{11}$ Ibidem, s. 150.

${ }^{12} \mathrm{~W}$ polskich opracowaniach okresu międzywojennego tłumaczono je jako Dekret o naczelnych zasadach prawa karnego RSFSR (np. w R. Lemkin, Kodeks karny Rosji Sowieckiej 1927, Warszawa 1928, s. 9), a we współczesnych: Przewodnie zasady prawa karnego. Zob. K. Sójka-Zielińska, Historia prawa, Warszawa 1993, s. 361; M. Filar, W stużbie utopii. 73 lata radzieckiego prawa karnego, Toruń 1992, s. 13-14. A. Bosiacki, Utopia..., s. 225-231.

${ }^{13}$ A. A. Gercenzon, Prawo karne. Część ogólna, Warszawa 1952, s. 105-107.

${ }^{14}$ W 1919 r. został członkiem Komisji Kodyfikacyjnej (od 1920 wiceprezes jej sekcji prawa karnego). Od 1 stycznia $1921 \mathrm{r}$. wykładał prawo karne jako profesor nadzwyczajny Uniwersytetu Warszawskiego. Podczas wojny polsko-radzieckiej od 1920 r. był prokuratorem Najwyższego Sądu Wojskowego. Sprawował funkcję ministra sprawiedliwości w 3 kolejnych rządach (28 VI 1922-26 V 1923) oraz w kolejnych gabinetach Kazimierza Bartla (15 V-30 IX 1926), gdzie odegrał znaczącą rolę w opracowaniu rządowego projektu o zmianie konstytucji (tzw. nowela sierpniowa 1926). Był posłem na Sejm 
Publikacją, w której W. Makowski bezpośrednio ustosunkował się do radzieckiego prawa karnego była przedmowa do Kodeksu karnego Rosji Sowieckiej 1927. Zwrócił on uwagę na kilka jego charakterystycznych prawidłowości ${ }^{15}$. Stwierdził przede wszystkim niespotykaną $\mathrm{w}$ innych ustawodawstwach zmienność tego prawa, gdyż poprzedni kodeks obowiązywał zaledwie pięć lat. Uwaga ta na pewno była trafna ze względu na liczbę źródeł prawa karnego wydanych od początku przejęcia władzy przez bolszewików. Zaczęło się od rozlicznych dekretów a skończyło na dwóch kodeksach $(1922,1926)$. Porównując jednak oba kodeksy, można stwierdzić, że pod względem celów i metod polityki karnej w istocie nie różniły się od siebie. Kodeks karny z 1926 r. powstał bardziej pod wpływem zmian politycznych niż ideologicznych. Po utworzeniu w grudniu $1922 \mathrm{r}$. ZSRR i wydaniu w 1924 r. nowej konstytucji opracowano (31 października 1924 r.) tzw. Zasady przewodnie ustawodawstwa karnego ZSRR. Służyło to ujednoliceniu i ustaleniu kompetencji federacyjnych i republikańskich organów ustawodawczych w dziedzinie ustawodawstwa karnego ${ }^{16}$. Wszystkie podstawowe założenia kodeksu karnego z 1922 r. pozostały w „nowym”. Mam tu na myśli jego stałe elementy, które obowiązywały w radzieckim prawie karnym aż do 1958 r.:

- klasowość - ustawodawstwo karne RSFSR miało za zadanie chronić socjalistyczne państwo robotników i chłopów oraz zaprowadzonego w nim porządku prawnego;

- funkcja ochronna socjalistycznego państwa robotników i chłopów oraz zaprowadzonego w nim porządku prawnego za wszelką cenę, a w związku tym odrzucenie funkcji gwarancyjnych;

- występowanie materialnej definicji przestępstwa - czyn społecznie niebezpieczny;

- oparcie odpowiedzialności karnej na zasadzie analogii (analogia legis);

- prawa karne miało być narzędziem w rękach klasy robotniczo-chłopskiej do realizacji celów wychowawczych, ideologicznych i politycznych;

- radziecki kodeks karny nie był aktem prawnym skończonym, zamkniętym, gdyż ciągle uzupełniano go rozlicznymi dekretami.

w latach 1928-1930 z listy Partii Pracy, a w latach 1930-1935 z listy Bezpartyjnego Bloku Współpracy z Rządem (od 1931 wicemarszałek Sejmu; 1928-1935 przewodniczący Sejmowej Komisji Konstytucyjnej). W latach 1935-1938 już jako senator związał się z Obozem Zjednoczenia Narodowego. W latach 1938-1939 ponownie wybrano go na posła i marszałka Sejmu. Do jego najwartościowszych publikacji zalicza się: Na drodze do reformy konstytucji (Warszawa 1929); Nowa Polska w nowej Europie (Warszawa 1930); Kodeks karny 1932. Komentarz (Warszawa 1933); Państwo społeczne (Warszawa 1936); My i Wy (Warszawa 1938); Nauka o państwie (Warszawa 1939). Więcej o W. Makowskim zob. W. T. Kulesza, Wacław Makowski o państwie społecznym, Warszawa 1998; K. Pol, Poczet prawników polskich, Warszawa 2000, s. 1049-1065.

${ }^{15}$ R. Lemkin, Kodeks karny..., s. 5-7.

${ }^{16} \mathrm{~W}$ art. 3 Zasad przewodnich... zastrzeżono, że z wyjątkiem przestępstw przeciwko państwu i przestępstw wojskowych poszczególne rodzaje przestępstw i ich karalność miały określać ustawy karne republik związkowych 
Uwagi W. Makowskiego znacznie rozwinął w tej samej publikacji R. Lemkin ${ }^{17}$ (już wtedy uczeń-seminarzysta W. Makowskiego na UW) we wstępie pt. Dzieje i charakter kodeksu karnego Rosji Sowieckiej (R.S.F.S.R ${ }^{18}$. Analizując rozwój radzieckiego ustawodawstwa ustalił, iż carski kodeks kar głównych i poprawczych z roku 1885 nie został od razu zniesiony i obowiązywał do 30 listopada $1918 \mathrm{r}$. Władze radzieckie zezwalały na jego stosowanie o tyle, o ile dane przepisy nie pozostawały w sprzeczności z „rewolucyjnym sumieniem” i „rewolucyjnym porządkiem prawnym"(Dekret o sądzie nr 1 z 24 listopada 1917 r.). Zdaniem R. Lemkina, dopiero 30 listopada 1918 r. Wszechrosyjski Centralny Komitet Wykonawczy wydał „postanowienie o ludowych sądach Rosyjskiej Socjalistycznej Republiki”, gdzie zawarte były następujące zasady: „Przy rozpatrywaniu wszystkich spraw sądy ludowe stosują dekrety robotniczo-włościańskiego rządu, a w braku odpowiedniego dekretu lub na wypadek niedostateczności tegoż kierują się socjalistycznym poczuciem prawnym”, i dalej: „zabrania się powoływania się w wyrokach i postanowieniach na ustawy obalonych rządów”. Tak więc cytowane „postanowienie” całkowicie zakazało stosowania carskiego ustawodawstwa karnego, nie tworząc jednak własnego. „Rosja sowiecka - pisał - weszła więc w okres prawa ustnego. Przy rozpatrywaniu przestępstw sądy nie były związane żadnymi ustawami”. Zauważmy, że R. Lemkin całkowicie pominął w swoich rozważaniach Dekrety o sądzie nr 2 i 3 i w związku z tym nie można chyba do końca zgodzić się z jego tezą o funkcjonowaniu jedynie „ustne-

${ }^{17}$ Rafał Lemkin urodził się w 1901 r. we wsi Bezwodne, powiat wołkowyski, w ówczesnej guberni grodzieńskiej. Uzyskał doktorat na Uniwersytecie Jana Kazimierza we Lwowie. Pod koniec lat dwudziestych był sekretarzem w Sądzie Apelacyjnym w Warszawie. Od 1934 r. przeszedł do adwokatury i praktykował w Warszawie. Swoją wiedzę pogłębiał na Uniwersytecie Warszawskim na seminarium Wacława Makowskiego. Związał się z Katedrą Prawa Karnego Wolnej Wszechnicy Polskiej w Warszawie, gdzie był starszym asystentem oraz wykładowcą prawa karnego porównawczego. Pełnił też funkcję sekretarza generalnego polskiej grupy Międzynarodowego Stowarzyszenia Prawa Karnego. Na V Konferencji dla Unifikacji Prawa Karnego w Madrycie w r. 1933 (organizowanej przez Ligę Narodów) przedstawił raport Czyny stanowiące zagrożenie ogólne (międzypaństwowe) uznane za przestępstwa prawa narodów. W raporcie tym sformułował pojęcie „przestępstwa barbarzyństwa”, które w 1944 r. doprowadziło do stworzenia terminu „ludobójstwo”. W kwietniu 1941 r. wyjechał do USA. Tam rozpoczął pracę na Duke University w Durham.W USA pełnił służbę we władzach federalnych. W Trybunale Norymberskim R. Lemkin został mianowany doradcą głównego amerykańskiego oskarżyciela, sędziego Sądu Najwyższego USA R. H. Jacksona. Od 1948 r. był profesorem prawa międzynarodowego na Yale University, a w roku akademickim 1955/1956 w Law School Rutgers University, kontynuując swoje studia nad problematyką ludobójstwa. W latach 50. był dwukrotnie przedstawiony do Pokojowej Nagrody Nobla. Zmarł nagle 28 sierpnia 1959 r. Pośmiertnie R. Lemkin został uhonorowany przez ONZ. O R. Lemkinie pisał głównie Ryszard Szawłowski: Rafał Lemkin - twórca pojęcia „ludobójstwo" i główny architekt Konwencji z 9 XII 1948 (w czterdziestolecie śmierci), „Państwo i Prawo” (dalej: PiP), z. 10, Warszawa 1999, s. 74-86; Rafał Lemkin, „Rzeczpospolita”, nr 196 z 23 sierpnia 1999 r.; Encyklopedia „biatych plam”, hasło: Lemkin Rafał, t. XI, Radom 2003. W pracach: Polski słownik biograficzny i Poczet prawników polskich autorstwa Krzysztofa Pola (Warszawa 2000) nie ma informacji na temat Rafała Lemkina. Zob. też S. Ziembicki, Kilka uwag o Rafale Lemkinie twórcy pojęcia „genocyd”, [w:] M. Marszał, J. Przygodzki (red.), Wybitni prawnicy na przestrzeni wieków, Wrocław 2006, s. 250-259.

${ }^{18}$ Ibidem, s. 8-9. 
go prawa karnego" ${ }^{19}$. Omawiając kolejne etapy powstawania kodeksu karnego z 1926 r. R. Lemkin zauważył, że Przewodnie zasady prawa karnego z 1919 r., zawierające fragmenty myśli prawnych, pozbawione charakteru kodyfikacji, wyrażały zasadę, że w społeczeństwie klasowym przestępstwo jest wynikiem warunków społecznych, wśród których przestępca żyje, kara nie jest odpłatą ani też ekspiacją winy, lecz jedynie i wyłącznie środkiem ochrony społecznej. Ponadto zwrócił uwagę, iż dekret ten nie wyszczególnił środków ochrony społecznej, nie określił stanów faktycznych, pozostawiając sądom na tym polu dotychczasowa swobodę. „Pierwszą normalną kodyfikacją sowiecką", jak określił, był kodeks karny RSFSR z roku 1922. Rewolucyjny i klasowy kodeks za cel kary uważał ochronę społeczeństwa, a nie odpłatę. W tym względzie można dostrzec wiele niekonsekwencji, gdyż obok środków ochrony społecznej wprowadzono także zwykłe środki karne.

Interesujące i kluczowe są rozważania W. Makowskiego na temat wpływu pozytywnej, włoskiej szkoły prawa karnego na sowieckie ustawodawstwo karne, a w szczególności na kodeks z r. $1927^{20}$. Stwierdził mianowicie, że w kodeksie radzieckim doszło jedynie do powierzchownej zmiany kary na „środek ochrony społecznej" ${ }^{21}$. W. Makowski miał w tym względzie wiele do powiedzenia, gdyż był wśród karnistów II Rzeczypospolitej wybitnym i uznanym przedstawicielem kierunku ściśle socjologicznego ${ }^{22}$. Państwo i społeczeństwo stanowiły dla niego wartości nadrzędne i dlatego były w jego koncepcjach punktem odniesienia do pojęć przestępstwo i kara. Przyjmując, że państwo jest koniecznością rozwoju społeczeństwa, definiował przestępstwo i karę wyłącznie przez instytucję państwa. Traktowanie przestępstwa jako czynu zabronionego przez państwo oznaczało jednocześnie przyjęcie społecznego charakteru przestępstwa. Już w swej pracy z r. 1911 W. Makowski krytycznie wypowiadał się na temat kary, ale też dostrzegał niebezpieczeństwa tkwiące $\mathrm{w}$ środkach ochrony społecznej (np. dowolność w ustalaniu stanów niebezpieczeństwa). Na V Zjeździe prawników i ekonomistów polskich w 1912 r. zastanawiał się nawet nad ewentualnym zniesieniem zasady nulla poena sine lege, bo czasami większe niebezpieczeństwo

${ }^{19}$ Widzimy rozbieżności z ustaleniami R. Lemkina w porównaniu z opiniami współczesnych polskich historyków prawa (A. Bosiackiego, T. Maciejewskiego, S. Płazy i K. Sójki-Zielińskiej), którzy twierdzą, że dopiero Dekret o sadzie nr 3 całkowicie zakazywał stosowania przedrewolucyjnego prawa.

${ }^{20}$ R. Lemkin, Kodeks karny..., s. 5-7.

${ }^{21}$ Radziecki kodeks karny wprowadził środki ochrony społecznej, usiłując $\mathrm{w}$ ten sposób usunąć z terminologii element karny. W myśl art. 9 KKR: „Środki ochrony społecznej stosuje się w celu: a) zapobieżenia nowym przestępstwom ze strony osób, które je popełniły; b) oddziaływania na innych niezdecydowanych członków społeczeństwa i c) przystosowania sprawców przestępstw do warunków współżycia w państwie pracy. Środki ochrony społecznej nie mogą mieć za cel wyrządzenia fizycznego bólu lub poniżenia godności ludzkiej i do odpłaty i kary nie zmierzają".

${ }^{22}$ M. Wąsowicz, Nurt socjologiczny w polskiej myśli prawnokarnej, Warszawa 1989, s. 68-78; J. Koredczuk, Wplyw nurtu socjologicznego na kształt polskiego prawa karnego procesowego w okresie międzywojennym (Les classiques modernes), Wrocław 2007, s. 61-62. 
tkwi w człowieku, który dotąd zbrodni nie popełnił, niż w przypadkowym przestępcy. Proponował, by w stosunku do społecznie niebezpiecznych ludzi („osobnik wobec powtórzenia i charakteru dokonanych czynów zbrodniczych, wobec stanu umysłowego, nałogów życiowych i sposobów życia uzewnętrznionego w czynie zbrodniczym") stosować środek ochronny w postaci umieszczenia w specjalnie do tego celu urządzonych instytucjach. Z czasem jednak W. Makowski odstępował od możliwości stosowania środka zabezpieczającego wobec osób potencjalnie niebezpiecznych ${ }^{23}$. Krytycznie odnosił się do środków ochronnych, twierdząc, że nie różnią się one od kary i mogą naruszać prawa jednostki. Większe znaczenie przywiązywał do polityki społecznej, dążącej do likwidacji źródeł przestępczości. Na przełomie lat dwudziestych i trzydziestych ukształtował się ostatecznie jego światopogląd oparty na doktrynie solidaryzmu społecznego. Negatywnie odnosił się do wszelkich przejawów kolektywizacji, uprzedmiotawiania jednostki i społeczeństwa.

Mając tak ukształtowany i wypracowany pogląd na temat roli ustawodawstwa karnego we współczesnym państwie, nie dziwią zdecydowanie krytyczne słowa W. Makowskiego pod adresem twórców radzieckich kodeksów: „Autorzy [...] nie rozumieją, czy też udają, że nie rozumieją różnicy pomiędzy karą a środkiem ochronnym”. Bolszewicy dążyli do usunięcia z prawa i życia społecznego kary i zastąpienia jej środkami ochrony społecznej. Było to jednak zwykłe przemianowanie kary na „środek ochrony społecznej” bez jednoczesnej zmiany ich istoty. Pod nazwą wykorzystaną m. in. z włoskiej szkoły pozytywistycznej ukryto dawną karę ze wszystkimi jej podstawowymi cechami. Kodeks radziecki zachował w rzeczywistości dotychczasowe, pospolite środki karne, a nawet przywrócił te, które były sprzeczne z prawami człowieka i obywatela, z zasadą odpowiedzialności indywidualnej (ogłoszeniem wrogiem ludu pracującego, konfiskata majątku). Kodeks karny z roku 1927 nie wnosił żadnego postępu ani nawet głębszej reformy do zasad walki z przestępstwem $\mathrm{w}$ porównaniu $\mathrm{z}$ jej stanem przed rewolucją październikową ${ }^{24}$. „To nie jest nawet - pisał W. Makowski - przelewanie nowego wina do starych beczek, to po prostu opatrywanie nowymi modnymi etykietami starych wyschłych butelek"25.

Z poglądami W. Makowskiego zgadzał się w pełni R. Lemkin, który wskazywał, że dorobek włoskiej szkoły prawa karnego był znany twórcom sowieckich kodeksów. W szeregu instytucji kodeksu karnego z 1927 r. widoczny był jej formalny wpływ. Odnosiło się to przede wszystkim do tzw. „stanu niebezpieczne-

${ }^{23}$ W komentarzu do kodeksu karnego z 1932 r. W. Makowski pisał, że stan niebezpieczny zachodzi wówczas, ,jeżeli człowiek ze względu na swój charakter, skłonności, nałogi, sposób życia, ze względu na nienormalność psychiczną, całkowitą lub częściową itd. jest groźny dla porządku prawnego".

${ }^{24}$ R. Lemkin, Kodeks karny..., s. 5-7.

${ }^{25}$ Ibidem, s. 6. 
go" ${ }^{26}$. Art. 7 kodeksu karnego RSFRR (dalej: k.k.R.) stanowił: „W stosunku do osób, które popełniły społecznie niebezpieczne czyny lub które są niebezpieczne ze względu na ich łączność z przestępczym środowiskiem lub ze względu na ich przeszłą działalność, mają zastosowanie środki ochrony społecznej o charakterze sądowo-poprawczym, leczniczym lub leczniczo-wychowawczym"27. Stan niebezpieczny był tu ujęty bardzo szeroko, w konsekwencji według cytowanego artykułu można było znaleźć się w kolizji z prawem karnym nawet bez popełnienia konkretnego czynu przestępczego.

Stworzony w k.k.R. system tzw. środków ochrony społecznej był nieudolną próbą kalkowania dorobku włoskiej szkoły prawa karnego. Analizując go, R. Lemkin powołał się wprost na opinię W. Makowskiego, który stwierdził, że kodeks sowiecki jedynie „proklamował” usunięcie elementu kary przez zastąpienie go elementem ochrony społecznej. Ogłoszenie wrogiem ludzi pracy jako najsurowszego spośród środków o charakterze sądowo-poprawczym uznał za instytucję typowo odwetową. W art. 21 k.k.R. „wstydliwie” - jak określił R. Lemkin - ukryto karę śmierci: „Dla walki z najbardziej ciężkimi przestępstwami zagrażającymi podstawom władzy sowieckiej i ustroju sowieckiego, aż do odwołania przez Centralny Komitet Wykonawczy ZSRR wypadkach, specjalnie przewidzianych w poszczególnych artykułach niniejszego kodeksu, stosuje się rozstrzelanie jako wyjątkowy środek ochrony państwa ludzi pracy"28.

Skromne objętościowo uwagi krytyczne W. Makowskiego, rozwinięte przez R. Lemkina, są niezwykle cenne, głównie ze względu na fakt, że już wtedy obaj

${ }^{26}$ I. Andrejew, rozważając na temat rodowodu społecznego niebezpieczeństwa czynu konstatuje, iż mimo wpływów szkoły socjologicznej na prawo radzieckie, w pierwszym okresie jego istnienia trudno jest powiązać koncepcję „społecznego niebezpieczeństwa czynu” z twórczością Liszta lub innego teoretyka szkoły socjologicznej. I. Andrejew, Podstawowe pojęcia nauki o przestępstwie, Warszawa 1988, s. $102-103$.

${ }^{27}$ R. Lemkin, Kodeks karny..., s. 21.

${ }^{28}$ Ibidem, s. 26. O roli szkoły pozytywistycznej we Włoszech R. Lemkin pisał więcej w publikacji pt. Kodeks karny faszystowski. Otóż - jak podaje R. Lemkin - we wrześniu 1919 r. „przywódcy szkoły pozytywistycznej", Enrico Ferriemu, powierzono kierownictwo nad pracami komisji mającej przygotować projekt nowego kodeksu karnego. W styczniu $1921 \mathrm{r}$. komisja przedłożyła go (zawierał tylko część ogólną) ministrowi sprawiedliwości. „Projekt ten - w opinii R. Lemkina - dokonał przewrotu w ustawodawstwie karnym, przesuwając punkt ciężkości z winy na niebezpieczeństwo, z przestępstwa na przestępcę, z kary na środki zabezpieczające, z odpłaty na zabezpieczenie”. I dalej podaje: „Projekt Ferriego oparł się na zasadniczej idei szkoły pozytywistycznej, przyznającej państwu jedynie prawo obrony przed społecznie niebezpiecznymi jednostkami, a odmawiającej zasadniczo państwu praw badania winy moralnej sprawcy. [...] Zresztą zagadnienie takie należeć powinno, zdaniem Ferriego, do religii, etyki i filozofii, a nie do prawa. [...] Państwo powinno zatem interesować się tylko szkodliwością sprawcy dla społeczeństwa, a stopień niebezpieczeństwa, grożącego społeczeństwu ze strony sprawcy, powinien być jedyną przesłanką dla zastosowania odpowiednich sankcji. Sprawcy nie należy karać, lecz po zbadaniu charakteru jego osobowości należy go albo usunąć ze społeczeństwa, albo starać się o jego poprawę, o ile jest to możliwe. Kara zatraca więc charakter odpłaty, a nabiera charakteru celowości”. A zatem celowość kary nakazuje stosować ją do wszystkich społecznie niebezpiecznych jednostek, bez względu na ich winę moralną. W projekcie tym karę zastąpiono sankcją ochrony społecznej, nadając jej charakter zabezpieczający, a nie represyjny. $Z$ powodu zmian politycznych we Włoszech nigdy on jednak nie wszedł w życie. R. Lemkin, Kodeks karny faszystowski, Warszawa 1929, s. 8-10. 
prawnicy podważali spotykane do dziś w piśmiennictwie zachodnim przekonanie o adaptacji w radzieckim prawie karnym tez i poglądów szkoły pozytywistycznej włoskiej. „Aczkolwiek poglądy te zdobyły sobie pewną popularność w doktrynie radzieckiej tego okresu - pisze M. Filar - o adaptacji nie może być mowy"29. Opinię tę - co prawda nie wprost - podzielali także inni prawnicy polscy okresu międzywojennego. Czynił to J. Makarewicz - wybitny karnista, przedstawiciel kierunku prawnonaturalnego w nurcie socjologicznym polskiej myśli prawno karneje W Kodeksie karnym... jednoznacznie potępił usankcjonowanie w radzieckim kodeksie karnym z 1922 r. materialnej definicji przestępstwa, zasady analogii i celowościowo-odstraszającego systemu kar, pisząc, iż „wszystkie te postanowienia wskazują, że mamy do czynienia z kodeksem karnym o charakterze politycznym, rewolucyjnym, że uwaga ustawodawcy skierowana jest na tępienie ludzi o przeciwnym, niż panujący, poglądzie społecznym i prawnym”31. Wprowadzenie „tych nowości” do kodeksu (z r. 1926) było z kolei - zdaniem K. Müllera - konieczne i celowe, ponieważ ustawodawca radziecki wyeliminował z niego zasadę nullum crimen sine lege poenali, na której opierają się wszystkie współczesne kodeksy karne. „Aby uzasadnić wyrugowanie tej zasady z kodeksu, zostały środki karne przefasonowane na środki ochrony społecznej. Skoro bowiem usunięta została $\mathrm{z}$ kodeksu poena - zbędna okazała się zdaniem ustawodawców sowieckich zasada nullum crimen sine lege" 32 .

Argumenty W. Makowskiego wyraźnie też zainspirowały R. Sakowicza, który jakże trafnie dostrzegł, że idea stosowania środków ochrony społecznej (zamiast kary) przyjęta została przez radzieckich prawników jedynie w interesie klasy panującej, tj. robotników i chłopów ${ }^{33}$. Należy tylko żałować, że tak interesująco zapowiadająca się w piśmiennictwie prawniczym II Rzeczypospolitej dyskusja na temat radzieckiego prawa karnego, rozpoczęta m.in. przez W. Makowskiego, została przerwana wydarzeniami wojennymi.

\footnotetext{
${ }^{29}$ M. Filar, $W$ stużbie utopii..., s. 20.

${ }^{30}$ M. Wąsowicz, Nurt socjologiczny..., s. 79-95; J. Koredczuk, Wplyw nurtu socjologicznego na ksztatt polskiego prawa karnego procesowego..., s. 58-61.

${ }^{31} \mathrm{~J}$. Makarewicz, Kodeks karny..., s. 12.

${ }^{32}$ K. Müller, Środki ochrony społecznej w sowieckim kodeksie karnym, „Wojskowy Przegląd Prawniczy" nr 1, Warszawa 1932, s. 8.

${ }_{33}$ R. Sakowicz, Kodeks karny Z.S.S.R. Jego przeszłość, teraźniejszość i przyszłość, Warszawa 1934, s. 7-8. Cytując A. Piątkowskiego, pisał dalej: „[...] dla pozostałych zaś obywateli sowieckich tego rodzaju przymusowe socjalno-poprawcze wychowanie jest pozbawione sensu, ponieważ naiwnym byłoby przypuszczać, że władza robotnicza mogłaby podjąć się zadania tego rodzaju wychowania w stosunku do swego wroga klasowego".
} 